\title{
Sunflowers genotypes agronomics features in the second harvest in Muzambinho (MG)
}

Guilherme Henrique Expedito Lense ${ }^{1}$

Fernanda Almeida Bócoli

Alberto Donizete Alves ${ }^{3}$

\begin{abstract}
The sunflower (Helianthus annuus L.) is an oilseed crop with agronomic features that justify its tillage in the southeast of Brazil. The objective of this work was to evaluate the agronomic performance of sunflower genotypes tallaged in Muzambinho (MG) in the second harvest. It was adopted the randomized blocks design, with six genotypes (MULTISSOL, BRS G35, BRS G47, BRS G48, M734, and SYN 045) and four repetitions, totalizing 24 experimental plots with an area of $16.8 \mathrm{~m}^{2}$ on its plot. The plant population adopted was about 45000 plants ha ${ }^{-1}$. The obtained data were submitted to the analysis of variance and the Tukey test, by $5 \%$ of probability. There was variation in the agronomic performance of the genotypes to all evaluate parameters. The variety of MULTISSOL was the genotype that presented the larger precocity. The hybrid SYN 045 presented the longer cycle. The hybrid M734 is the genotype with a bigger weight of 1.000 achenes. The genotypes that provided the better yield of grains and oil were M734, SYN 045 and BRS G48. The biggest oil content in the achenes was observed in SYN 045 and BRS G48.
\end{abstract}

Keywords: Helianthus annuus L. Flowering. Oil production.

\section{Introduction}

The sunflower (Helianthus annuus L.) is a yearly dicotyledonous of the Asteraceae family, presenting important agronomic features, as larger drought resistance, to cold and hot weather, than the majority of other tillage species in Brazil. Furthermore, it adapts in different edaphoclimatic conditions, its production is little influenced by the latitude, altitude, and photoperiod (CASTRO et al., 1997).

There are so many uses of the sunflower; the plant can be used to produce silage and with the grains manufacture animal feed. The oil can be extracted with high quality for human consumers or as raw material to produce biodiesel, the plant can be used as ornamental in decorations or the seeds to feed the birds (LEITE et al., 2005).

Due to this diversity of uses and its agronomic particularities, the sunflower crop generates an increasing demand of the industrial sector and commercial, thus it is a good economic alternative for the crop rotation, consortium, and succession in regions where the production of grains predominates (PORTO; CARVALHO; PINTO, 2007).

1 Universidade Federal de Alfenas, mestrando pelo Programa de Pós-Graduação em Ciências Ambientais. guilhermeelense@gmail.com. Rua Gabriel Monteiro da Silva, 700, Centro, 37130-000, Alfenas, Minas Gerais, Brasil.

2 Universidade Federal de Lavras, mestranda pelo Programa de Pós-Graduação em Ciência do Solo. fernanda.muz@hotmail.com.

3 Instituto Federal de Educação, Ciência e Tecnologia do Sul de Minas Gerais (IFSULDEMINAS) - Campus Muzambinho, professor. alberto. alves@muz.ifsuldeminas.edu.br. 
The sunflower plant area in Brazil in the 2014/2015 harvest corresponded to 111.5 thousand hectares with mean productivity of $1,374.0 \mathrm{~kg} \mathrm{ha}^{-1}$, in that agricole year, the state of Mato Grosso occupied the leadership in the national production, with 86 thousand hectares planted with 1,348.0 $\mathrm{kg} \mathrm{ha}^{-1}$ of productivity. Minas Gerais, on the other hand, presented 14 thousand hectares of sunflower cultivated in 2015, with a mean productive of $1,465.0 \mathrm{~kg} \mathrm{ha}^{-1}$, region characterized by seeding in the second harvest, occurring normally in March and April with its harvest between July and August (COMPANHIA NACIONAL DE ABASTECIMENTO, 2016).

The sunflower entering in the productive process and the increasing access by the producers in its planting is possible because, upon some technique adaptations, its productive chain uses the same machinery available for the production and processing of other grains, for example, the soybean (PIVETTA et al., 2012). Moreover, the adoption of sunflower cultivation in the second harvest is an alternative to produce grains and oil, whose oil presents a better market value than soybean oil used in human feeding, and, on the other hand, it can also diminish the beneficiaries industries idleness, result in an optimization of land use, machinery, and labor, in addition to favoring a creation and duration of employment in producers regions (CAPONE et al., 2012).

In sunflower production, among so many parameters to be observed before the crop introduction, the cultivars proper choice constitutes one of the main compounds of production system and, having in mind the existence of interaction of genotypes versus environment, some evaluations in test networks are necessary, in order to determinate the agronomic behavior of sunflower genotypes and its adaptation to a diversity of environments and local conditions (PORTO; CARVALHO; PINTO, 2007).

The information about the sunflower genotype performance in different regions are obtained mainly by the Evaluation Test Networks of Sunflowers Genotypes, that consists in a diversity of experiments carried out since 1989 in many regions in the country, aiming the selection and evaluation of sunflower genotypes of various companies and other institutions, coordinated by Embrapa Soja and conducted by public and private entities (PORTO et al., 2009).

Each year new genotypes are evaluated in diverse cultivation regions that exert a strong influence in sunflower adaptation, at which the materials that present the best agronomic features and adaptation are selected; based on that information, the choice of the producer is facilitated in regions with similar edaphoclimatic conditions (DALCHIAVON et al., 2016).

The sunflower cultivation expansion in the country can be favored by the selection of verities or hybrids with high productivity and adaptability in different regions, however, more studies that identify the best genotypes for each Brazilian region are necessary. In this context, this work aimed to evaluate the sunflower genotypes agronomic characteristics planted in the second harvest in Muzambinho, in the South of Minas Gerais, and to determinate what genotypes present the best performance in that region.

\section{Material and methods}

The experiment was conducted from March to July in 2016, in the second harvest period, located at $21^{\circ} 20^{\prime} 67^{\prime \prime}$ South and $46^{\circ} 32^{\prime} 22^{\prime \prime}$ West, $1.033 \mathrm{~m}$ of altitude. The work is one of the experiments of Evaluation Test Networks of Sunflowers Genotypes, coordinated by Embrapa Soja.

The climate of these regions is classified as Cwb, according to Köppen Climate Classification, humid tempered, with dry winter and summer moderately hot (SÁ JÚNIOR et al., 2012). The mean temperature during the experiment was $18.8^{\circ} \mathrm{C}$, with maximum and minimum temperatures means of $25.6^{\circ} \mathrm{C}$ and $14.0^{\circ} \mathrm{C}$ respectively. The total occurred rainfall was $414.2 \mathrm{~mm}$, concentrated mainly 
in March and in end of May and beginning of June. Figure 1 represents the climate data collected, in a meteorological station next to the experimental area:

Figure 1 - Climatic conditions during the period of conduction of the experimental network.

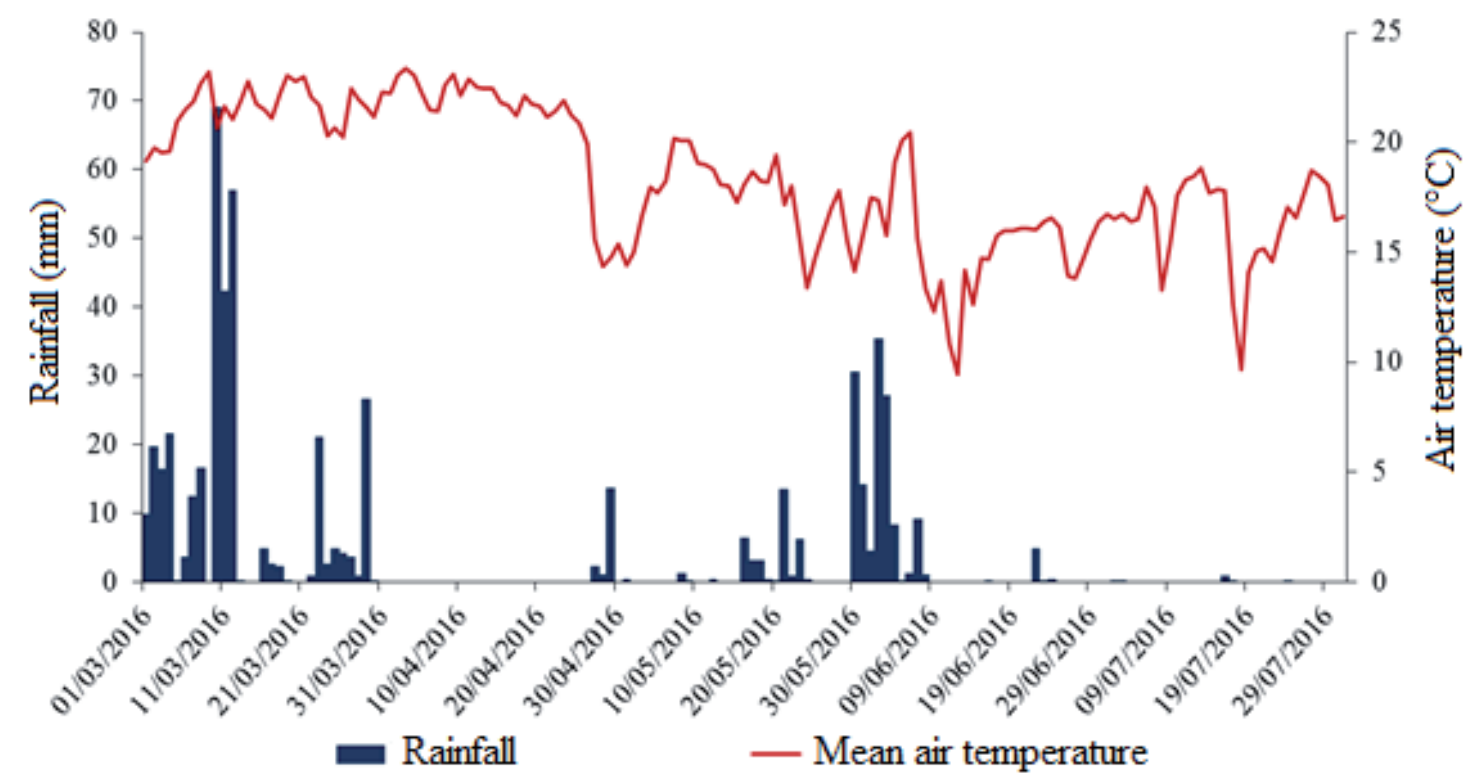

Source: Elaborated by the authors (2016).

The study adopted randomized blocks design, with six genotypes corresponding to the treatments, of two varieties: MULTISSOL, BRS G35; and four hybrids: BRS G47, BRS G48, M734 and SYN 045, of which two were witness treatments (M734 e SYN 045), corresponding to the more commercial genotypes. It was carried out four repetitions, totalling 24 experimental plots. The experimental plots were constituded of 4 lines with $6 \mathrm{~m}$ length, with line spacing of $0.7 \mathrm{~m}$; containing $16.8 \mathrm{~m}^{2}$ of area for each portion. Only the two central lines $(5.0 \mathrm{~m})$ were utilized as a useful area for evaluation $\left(7.0 \mathrm{~m}^{2}\right)$.

The soil of the area in this study was classified as Eutrophic Red Latosol, the seeding was carried out on March, 23, 2016, to a depth of three centimeters, adopting tree seeds to each planting hole, with a hand application of $286.0 \mathrm{~kg} \mathrm{ha}^{-1}$ of N-P-K (08-28-16) according to the soil analyze (TABLE 1) and the nutritional exigencies of the crop.

Table 1 - Soil analyze result of the experimental area in Muzambinho (MG), January, 2016.

\begin{tabular}{|c|c|c|c|c|c|c|c|c|c|c|c|c|c|}
\hline \multirow{2}{*}{$\mathrm{pH}^{1}$} & $\mathrm{MO}^{2}$ & $\mathbf{P}^{3}$ & $\mathrm{~K}^{3}$ & $\mathrm{Ca}^{4}$ & $\mathrm{Mg}^{4}$ & $B^{5}$ & $\mathrm{Al}^{4}$ & $\mathrm{H}+\mathrm{Al}$ & SB & $t$ & $\mathbf{T}$ & V & M \\
\hline & dag kg $^{-1}$ & \multicolumn{2}{|c|}{$\mathrm{mg} \mathrm{dm}^{-3}$} & \multicolumn{8}{|c|}{$\mathrm{cmol} \mathrm{dm}^{-3}$} & \multicolumn{2}{|c|}{$\%$} \\
\hline 6.4 & 3.14 & 13.3 & 300 & 3.4 & 1.4 & 0.3 & 0 & 2.5 & 5.5 & 5.5 & 8 & 69 & 0 \\
\hline
\end{tabular}

${ }^{1} \mathrm{pH}$ in water; ${ }^{2}$ oxi-redution; ${ }^{3}$ Extractor: Mehlich-1; ${ }^{4}$ Extractor: $\mathrm{KCl} 1 \mathrm{~mol} \mathrm{~L}-1$; ${ }^{5}$ hot water; SB: Sum of bases; t: effective CTC; T: CTC in pH 7; V: Bases saturation; m: Aluminum Saturation.

Source: Elaborated by the authors (2016). 
The emergency took place on March 28, with about $100 \%$ of emerged plants, and seven days after emergence (DAE), the thinning was conducted, leaving only 21 plants by a line, representing one population of about 45 thousand plants ha-1. At $30 \mathrm{DAE}$, covering fertilizing in a dose of 148.0 $\mathrm{kg} \mathrm{ha}{ }^{-1}$ of NPK (25-00-25) and $2.0 \mathrm{~kg} \mathrm{ha}^{-1}$ of boric (Boric acid) was carried out.

Regarding the weeds plant's control in the area, it was carried out a hand weeding, with the aid of a hoe. To control the sunflower black caterpillar (Chlosyne lacinia saundersii Doubleday \& Hewilson), the application of Acetamiprid + Alfa-Cypermethrin, in a dose of $0.3 \mathrm{~L} \mathrm{ha}^{-1}$ was carried out. About the leaf disease occurrence, it wasn't done the control because of the low incidence, although it was observed the moderate occurrence of Sclerotinia sclerotiorum. The main problem observed was a severe Bird (Pionus maximiliani) attack, being necessary bagging the late genotypes.

The harvest took place when the genotypes overtake the physiologic maturation, being the last genotype harvested on July, 27, 2016, the chapters were conditioned in the greenhouse to drying.

The evaluated features was: days after seeding to initial flowering (DIF): noted when $50 \%$ of the plants of two central lines of the portion were in phenological stage R4; days after seeding to physiologic maturing (DPM): when $90 \%$ of the plants in the useful portion present chapters with the bracts in the color between yellow and brown, with $30 \%$ humidity in the achenes; plant height $(\mathrm{PH}$, in $\mathrm{cm})$ : obtained through the mean of ten plants in the useful area measured in full flowering in the level of the soil until the insertion of the chapter; stalk curvature (SC): visual evaluation using the classification scale of Castiglioni et al. (1997); chapter size (CS): obtained through the mean of $20 \%$ the plants of the useful area of the portion, measured in the physiologic maturation point; weight of thousand achenes (W1000, in $\mathrm{g}$ ): obtained by the direct score of 1.000 achenes and posterior weighing of them in the precision balance; grains productivity in $\mathrm{kg} \mathrm{ha}^{-1}$ : considering twenty-one plants of two central lines of the portion as parameter, corrected by $11 \%$ of humidity; oil content (\%): determinate by solvent petrol eter in an extractor Soxhlet, second AOCS methodology (1997) and carried out by Soybean Embrapa; lastly, oil content was estimated in $\mathrm{kg} \mathrm{ha}^{-1}$ by using the productivity data and oil content.

The obtained experimental data were submitted on the variance analysis by the $\mathrm{F}$ test and the treatments mean compared by the Tukey test, at $5 \%$ of probability, with the aid of the Sisvar ${ }^{\circledR}$ statistical program (FERREIRA, 2011).

\section{Results and discussion}

During the conduction of the experimental testing, the rainfall $(414.2 \mathrm{~mm})$ was a little bit bellow of the crop hydraulic demand, as sunflower requires an accumulated rainfall of 500 to 700 $\mathrm{mm}$ distributed regularly during its cycle (CASTRO et al., 1997). The manifested sunflower agronomic features can be influenced by the low rain index, however rainfall happened in the periods of bigger crop necessity, especially, during the flowering.

To all evaluated parameters, it was verified a significative effect by $F$ test $(p<0.05$ ), indicating that the environmental conditions of Muzambinho (MG) influenced in a unique way the genotypes behavior. In all sunflower agronomic features analyses, the variation coefficients (VC) were presented inferiors to $10 \%$, values considered low (GOMES, 1990), indicating reliability in the data and good experimental precision.

The witness SYN 045 presented the latter initial flowering (DIF) genotype (80 days) while the MULTISSOL cultivar presented the earlier (60 days), both differing statistically among them and the 
others (TABLE 2). The witness M734, the hybrid BRS G47 and the variety BRS G35 did not differ among them, but differed of BRS G48. Massignam and Angelocci (1993) related the low interference of climatic factors in the sunflower initial flowering. On the other hand, Nobre et al. (2012) mentioned that the variation in these features can be related mainly to the genotype properly.

As for physiological maturation, the witness SYN 045 and M734 were the latter genotypes (125 e 122.3 days respectively), and it did not present statically difference among each other. The variety MULTISSOL presented the littler period to reach the physiological maturation, corresponding, in this case, to 109 days, what is very relevant because, for the second harvest planting, earlier cycle cultivars are indicated earlier, in order to diminish the flowering phase hydraulic stress risk (NETO et al., 2000).

Besides, when compared to latter cultivars, earlier cultivars and the ones that are in the field for a shorter period are less exposed to pest-insects incidence and diseases, and if an efficient control of its agents is not carried out, the short time on the field can reduce production risks (DALCHIAVON et al., 2016).

Dalchiavon, Malacarne and Carvalho (2016) stated that the hybrid M734, when cultivated in Campo Novo do Parecis (MT), reached the physiological maturation in 97 days after planting. In Muzambinho (MG), this hybrid only reaches the physiological maturation in 122.3 days. This difference justifies mainly in virtue of climates influence, once in South of Minas Gerais the clime is milder growing the sunflower cycle.

Table 2 - Agronomic features mean results: days after seeding for the initial flowering (DIF), days after seeding to physiologic maturing (DPM), plant height (PH), stalk curvature (SC) and chapter size (CS) of different sunflower genotypes cultivated from March to July in 2016, Muzambinho, South of Minas Gerais.

\begin{tabular}{cccccc}
\hline Genotypes & \multicolumn{5}{c}{ Variaties } \\
\cline { 2 - 6 } & $\begin{array}{c}\text { DIF } \\
\text { (days) }\end{array}$ & $\begin{array}{c}\text { DPM } \\
\text { (days) }\end{array}$ & $\begin{array}{c}\text { PH } \\
\text { (cm) }\end{array}$ & SC & $\begin{array}{c}\text { CS } \\
\text { (cm) }\end{array}$ \\
\hline M734 & $68.0 \mathrm{c}$ & $122.3 \mathrm{ab}$ & $129.5 \mathrm{~b}$ & $5.0 \mathrm{a}$ & $16.6 \mathrm{ab}$ \\
SYN 045 & $80.0 \mathrm{a}$ & $125.0 \mathrm{a}$ & $152.0 \mathrm{a}$ & $4.0 \mathrm{~b}$ & $17.4 \mathrm{a}$ \\
BRS G47 & $68.3 \mathrm{c}$ & $114.0 \mathrm{~d}$ & $141.5 \mathrm{ab}$ & $4.0 \mathrm{~b}$ & $16.6 \mathrm{ab}$ \\
BRS G48 & $72.0 \mathrm{~b}$ & $119.0 \mathrm{c}$ & $139.5 \mathrm{ab}$ & $4.5 \mathrm{ab}$ & $16.9 \mathrm{a}$ \\
BRS G35 & $66.8 \mathrm{c}$ & $121.8 \mathrm{bc}$ & $128.3 \mathrm{~b}$ & $4.0 \mathrm{~b}$ & $16.5 \mathrm{ab}$ \\
MULTISSOL & $60.0 \mathrm{~d}$ & $109.0 \mathrm{e}$ & $95.5 \mathrm{c}$ & $5.3 \mathrm{a}$ & $15.2 \mathrm{~b}$ \\
Means & 69.2 & 118.5 & 131.0 & 4.5 & 16.5 \\
CV (\%) & 1.1 & 1.0 & 4.5 & 7.4 & 4.4 \\
\hline
\end{tabular}

Treatments means followed by the same letter in the column do not differ among each other by the Tukey test on $5 \%$ of probability.

Source: Elaborated by the authors (2016).

The hybrids BRS G47, BRS G48 and the witness SYN 045 presented larger mean plant height, being considered statistically equal, while the variety MULTISSOL demonstrated the minor mean when compared to all other genotypes (TABLE 2). 
The genotypes height general mean was $131.0 \mathrm{~cm}$, being considered short when compared to the experiment of Nobre et al. (2012), conducted in Mucambinho, north of Minas Gerais, also testing different sunflowers materials in the second harvest. In this case, the genotypes presented as mean plant height the value of $170.0 \mathrm{~cm}$. Lower plant height is one desirable characteristic, once shorter sunflower plants make the cultural treatment easier, being less propitious to breaking and bedding when submitted to weathering, tend to diminish the losses in mechanic harvest, besides providing larger chapter support (LEITE et al., 2005).

The bigger sunflower stalk curvature was observed for the witness M734, for the hybrid BRS G48 and for the variety MULTISSOL, which do not differ among them, presenting according to the Castiglioni et al. (1997) classification scale, means of 5.0, 4.5 and 5.3, respectively. Sharp stalk curvature can be considered an unfavorable aspect, because when associated to high wind velocities contributes to the plant bedding and breaking (SANTOS et al., 2011), although in relation to the birds incidence, common in the experimental area, the genotypes with sharp stalk curvature presented a positive effect with low damage occasioned by this eventuality.

The chapter size in its turn differed only among cultivar MULTISSOL, and the hybrids SYN 045 and BRS G48, which presented larger means (TABLE 2), indicating a favorable genotype aspect, once larger chapters diameters associated to optima climate conditions, maintenance of sunflower nutritional necessities and control of possible pests and diseases will result in a bigger achenes number and weight, generating productivity additions.

The witness M734 and the variety MULTISSOL were the genotypes that presented a 1.000 achenes larger weight with means corresponding to $75.4 \mathrm{~g}$ and $71.9 \mathrm{~g}$; being that the witness M734 differed of the others and the variety MULTISSOL did not differ only of the hybrid BRS G47 (TABLE 3).

The sunflower genotypes that own the genetic characteristic 1,000 achenes weight presented higher achenes productivity potential than materials with low weight, this characteristic is manifested according to environmental conditions and the crop management, stressing the appropriate agronomic practices importance (DALCHIAVON; MALACARNE; CARVALHO, 2016).

Table 3 - Evaluation of hybrids and varieties sunflower agronomic features cultivated from March to July in 2016, Muzambinho, South of Minas Gerais.

\begin{tabular}{ccccc}
\hline \multirow{2}{*}{ Genotypes } & \multicolumn{4}{c}{ Varieties } \\
\cline { 2 - 5 } & $\begin{array}{c}\mathbf{1 , 0 0 0} \text { achenes } \\
\text { weight } \mathbf{( g )}\end{array}$ & Grains yield $\left(\mathbf{k g ~ h a}^{-1}\right)$ & Oil content (\%) & $\begin{array}{c}\text { Oil yield } \\
\mathbf{~ ( k g ~ h a ~}^{-1} \text { ) }\end{array}$ \\
\hline M734 & $75.4 \mathrm{a}$ & $2185.6 \mathrm{a}$ & $39.7 \mathrm{~b}$ & $867.7 \mathrm{ab}$ \\
SYN 045 & $64.1 \mathrm{c}$ & $1842.9 \mathrm{bc}$ & $44.1 \mathrm{a}$ & $812.7 \mathrm{bc}$ \\
BRS G47 & $65.8 \mathrm{bc}$ & $1665.5 \mathrm{~cd}$ & $44.4 \mathrm{a}$ & $739.5 \mathrm{c}$ \\
BRS G48 & $61.1 \mathrm{~cd}$ & $2049.0 \mathrm{ab}$ & $45.3 \mathrm{a}$ & $928.2 \mathrm{a}$ \\
BRS G35 & $54.8 \mathrm{~d}$ & $1348.0 \mathrm{e}$ & $45.1 \mathrm{a}$ & $607.9 \mathrm{~d}$ \\
MULTISSOL & $71.9 \mathrm{ab}$ & $1481.2 \mathrm{de}$ & $39.3 \mathrm{~b}$ & $582.1 \mathrm{~d}$ \\
Means & 65.5 & 1726.0 & 43.0 & 756.4 \\
CV (\%) & 4.2 & 5.6 & 3.5 & 5.6 \\
\hline
\end{tabular}

Treatments means followed by the same letter in the column do not differ among each other by the Tukey test on $5 \%$ of probability.

Source: Elaborated by the authors (2016). 
The genotype BRS G48 was one of the materials with the bigger grains yield, estimated in 2,049.0 $\mathrm{kg} \mathrm{ha}^{-1}$, and it did not differ of both witness M734 and SYN 045, which differed statistically among them, the other results are expressed in Table 3. Even though the values differ in the productivity, only the variety BRS G35 presented a bottom mean in comparison to the productivity general means in 2015, in Minas Gerais, that corresponded to $1,465.0 \mathrm{~kg} \mathrm{ha}^{-1}$ (CONAB, 2016), indicating that the genotypes presented good productivity stressing the hybrids M734 and BRS G48.

The grains general yield mean was $1,726.0 \mathrm{~kg} \mathrm{ha}^{-1}$, a value higher than that found for Nobre et al. (2012), who assessing genotypes in the second harvest in Nova Porteirinha (MG) obtained the value of $1407.9 \mathrm{~kg} \mathrm{ha}^{-1}$ as mean productivity.

The hybrids BRS G47, BRS G48, and the variety BRS G35 presented oil content similar to the witness SYN 045 and higher to other materials. On the other hand, the genotypes M734 and MUTISSOL presented less oil content, do not differentiating between them and with means corresponding to $39.7 \%$ and $39.3 \%$ respectively. For the witness $M 734$, similar results were found by Pivetta et al. (2012), assessing sunflower hybrids in an experiment located in Palotina (PR), they found minor oil content for the material M734 corresponding to $35.05 \%$.

The major oil content hybrids selection is a factor relevant in the sunflower productive chain, once in the sunflower commercialization, some industries are paying the producers based on the achenes oil content instead of its weight. This is justified by the fact that one genotype with a larger achenes productivity per area do not necessarily results in a larger oil productivity in this same area, once the oil is the most wanted product at the end of this industrial process and considered the main product of this crop (IOCCA et al., 2015).

The soybean, main oilseed cultivated in the country, presents an oil content of $12.0 \%$ to 24.0\%, according to the environmental effects and the cultivars (SEDIYAMA et al., 1993), values much inferior to that found in this work with sunflowers, with genotypes means of $43 \%$.

The high oil content is one fact that favors the adoption of sunflower by the producers, and with the development of new technologies that perfect the cultivation, with the selection of favorable features genotypes production and disease resistance as the white mold (Sclerotinia sclerotiorum) and the popularization of cultivation, the sunflower can become a more advantageous option to produce oil than the other oilseeds including the soybean, gaining space in the national scene.

In relation to the estimative of oil content, the larger mean (928.2 $\mathrm{kg} \mathrm{ha}^{-1}$ ) was obtained from the hybrid BRS G48, and it did not differ only from the witness M734, demonstrating the oil potential production of these genotypes. The low means were observed to the varieties BRS G35 and MULTISSOL and they did not differ statistically from each other (TABLE 3).

It is valid to stress that, although the witness M734 has presented low oil content than the genotypes BRS G47 and BRS G35, its oil yield was larger in virtue of its elevated productivity. This fact highlights that when you opt to sunflower implantation with the end intent in the oil production, the adoption of cultivars that present high oil content on its achenes is a factor that has to be availed with other parameters with prominence for the productivity, besides being attentive for the correct management of the crop.

Regarding to the evaluate parameters based on the yield, the control test varieties M734 and SYN 045 presented, in general, better values than the other tested genotypes, except the hybrid BRS G48 that demonstrated a genotype with good productive features. 


\section{Conclusions}

The variety MULTISSOL was the genotype that presented the biggest precocity, however, this crop had the lowest productive rate, in this way, it can be used when the goal is not to produce grains (silage, soil covering, and so on).

Concerning the productive features, the genotypes M734, SYN 045 and BRS G48 presented the best results, being an advantageous alternative to be adopted by sunflowers producers in the South of Minas Gerais.

\section{Acknowledgements}

The authors thank the Fundação de Amparo à Pesquisa do Estado de Minas Gerais (FAPEMIG) for the scholarship offered to the first author. This study was financed in part by the Coordenação de Aperfeiçoamento de Pessoal de Nível Superior - Brasil (CAPES) - Finance Code 001.

\section{Características agronômicas de genótipos de girassol na segunda safra em Muzambinho - MG}

\section{Resumo}

O girassol (Helianthus annuus L.) é uma oleaginosa com características agronômicas que justificam seu cultivo no sudeste brasileiro. 0 objetivo do presente trabalho foi avaliar o desempenho agronômico de genótipos de girassol cultivados em Muzambinho (MG) na segunda safra. Foi adotado o delineamento em blocos casualizados (DBC), com seis genótipos (MULTISSOL, BRS G35, BRS G47, BRS G48, M734, e SYN 045) e quatro repetições, totalizando 24 parcelas experimentais com área de $16,8 \mathrm{~m}^{2}$ em cada parcela. Adotou-se uma população de aproximadamente 45.000 plantas ha-1. Os dados obtidos foram submetidos à análise de variância e ao Teste Tukey, a $5 \%$ de probabilidade. Ocorreu variação no comportamento agronômico dos genótipos para todos os parâmetros avaliados. A variedade MULTISSOL foi o genótipo que apresentou maior precocidade. 0 híbrido SYN 045 apresentou maior duração do ciclo. 0 híbrido M734 se mostrou como o genótipo com maior peso de 1.000 aquênios. Os genótipos que proporcionaram maiores rendimentos de grãos e de óleo foram M734, SYN 045 e BRS G48. Os maiores teores de óleo nos aquênios foram observados para SYN 045 e BRS G48.

Palavras-chave: Helianthus annuus L. Florescimento. Produção de óleo.

\section{References}

AMERICAN OIL CHEMISTS SOCIETY - AOCS. Official methods and recommended practices of the American Oil Chemists Society. 5.ed. Champaign, IL: AOCS, 1997.

CAPONE, A.; BARROS, H. B.; SANTOS; E. R. dos; CASTRO E. F; SANTOS, A. F. dos; FIDELIS, R. R. Efeito de épocas de semeadura de girassol na safrinha, em sucessão à soja no Cerrado Tocantinense. Revista Ceres, Viçosa, v. 59, n. 1, p. 102-109, jan/fev, 2012. 
CASTIGLIONI, V. B.; BALLA, A.; CASTRO, C. E.; SILVEIRA, J. M. Fases de desenvolvimento da planta de girassol. Londrina: Embrapa. 1997. 24 p.

CASTRO, C. de; CASTIGLIONI, V. B. R.; BALLA, A.; LEITE, R. M. V. B. C.; KARAM, D.; MELLO, H. C.; GUEDES, L. C. A.; FARIAS, J. R. B. A cultura do girassol. Londrina: Embrapa Circular Técnica, 13, 1997. 36p.

COMPANHIA NACIONAL DE ABASTECIMENTO - CONAB. Acompanhamento Safra Brasileira de Grãos, v. 9, Safra 2015/16 - Nono levantamento, Brasília, p. 1-178, junho 2016.

DALCHIAVON, F. C.; CARVALHO, C. G. P. de; AMABILE, R. F.; GODINHO, V. P. C.; RAMOS, N. P.; ANSELMO, J. L. Características agronômicas e suas correlações em híbridos de girassol adaptados à segunda safra. Pesquisa Agropecuária Brasileira, Brasília, v. 51, n. 11, p. 1806-1812, nov. 2016.

DALCHIAVON, F. C.; MALACARNE, B. J.; CARVALHO, C. G. P. de. Características agronômicas de genótipos de girassol (Helianthus annuus L.) em segunda safra no Chapadão do Parecis - MT. Revista de Ciências Agrárias, Lisboa, v. 39, p. 178-186, mar., 2016.

FERREIRA, D. F. Sisvar®: A computer statistical analysis system. Ciência e Agrotecnologia, Lavras, v. 35, n. 6, p. 1039-1042, 2011.

GOMES, F. P. Curso de estatística experimental. 12. ed. São Paulo: Nobel, 1990. 467 p.

IOCCA, A. F. S.; DALCHIAVON, F. C.; MALACARNE, B. J.; CARVALHO, C. G. P. de. Avaliação do teor e produtividade de óleo em genótipos de girassol. Reunião Nacional de Pesquisa de Girassol, 21., Simpósio Nacional sobre a Cultura do Girassol, 9., Londrina, Anais...Londrina/PR, p. 125-128, 2015.

LEITE, R. M. V. B. C.; BRIGHENTI, A. M.; CASTRO, C. de. Girassol no Brasil. Londrina: Embrapa Soja, 2005. 641p.

MASSIGNAM, A. M. E.; ANGELOCCI, L. R. Relações entre temperatura do ar, disponibilidade hídrica no solo, fotoperíodo e duração de sub-períodos fenológicos do girassol. Revista Brasileira de Agrometeorologia, Santa Maria, v. 1, n. 1, p. 63-69, 1993.

FARIAS NETO, A. L. F.; AMABILE, R. F.; AZEVEDO, J. A. de; FONSECA, C. E. L. da; CASTIGLIONI, V. B. Avaliação de variedades de Girassol nos Cerrados do Distrito Federal. Revista Ceres, Viçosa, v. 47, n. 273, p. 469-482, 2000.

NOBRE, D. A. C.; RESENDE, J. C. F. de; BRANDÃO-JÚNIOR, D. S.; COSTA, C. A. da; MORAIS, D. L. $B$. Desempenho agronômico de genótipos de girassol no norte de Minas Gerais. Revista Agroambiente On-line, Boa Vista, v. 6, n. 2, p. 140-147, maio-agosto, 2012. Disponível em: <https://revista.ufrr. br/agroambiente/article/ view/781 > . Acesso em: 04 set. 2017.

PIVETTA, L. G.; GUIMARÂES, V. F.; FIOREZE, S. L.; PIVETTA, L. A.; CASTOLDI, G. Avaliação de híbridos de girassol e relação entre parâmetros produtivos e qualitativos. Revista Ciência Agronômica, Fortaleza, v. 43, n. 3, p. 561-568, jul-set, 2012. 
PORTO, W. S.; CARVALHO, C. G. P.; PINTO, R. J. B. Adaptabilidade e estabilidade como critérios para seleção de genótipos de girassol. Pesquisa Agropecuária Brasileira, Brasília, v. 42, n. 4, p. 491 499, abr, 2007.

PORTO, W. S.; CARVAlHO, C. G. P. de; PINTO, R. J. B; OliVEIRA, M. F. de; OliVeiRA, A. C. B. de. Adaptabilidade e estabilidade de genótipos de girassol para a região subtropical do Brasil. Ciência Rural, Santa Maria, v. 39, n. 9, p. 2452-2459, dez., 2009.

SÁ JUNIOR, A.; CARVALHO, L. G.; SILVA, F. F.; ALVES, M. C. Application of the Köppen classification for climatic zoning in the state of Minas Gerais, Brazil. Theoretical and Applied Climatology, Wien, v. 108, p. 1-7, 2012.

SANTOS, A. R. dos; SALES, E. C. J.; ROCHA JÚNIOR, V. R.; PIRES, A. J. V.; REIS, S. T. dos; RODRIGUES, P. S. Desempenho de genótipos de girassol sob irrigação nas condições do semiárido. Revista Brasileira de Saúde e Produção Animal, Salvador, v. 12, n. 3, p. 594-606, 2011.

SEDIYAMA, T.; PEREIRA, M. G.; SEDIYAMA, C. S.; GOMES, J. L. L. Cultura da soja: parte I. ViçOsa, MG: UFV, 1993. 97p.

Received: July 11, 2018

Accepted: September 20, 2018 